\title{
The Effect of Storage Media on The Degree of Conversion of Different Types of Composite Resin
}

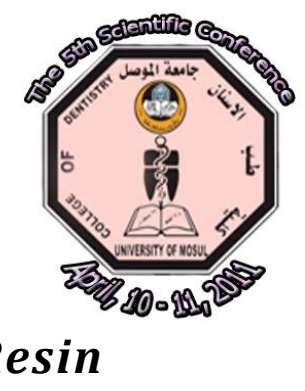

ABSTRACT
Aims: This study was performed to evaluate the effect of Pepsi, orange juice and coffee as storage media on the Degree of Conversion (DC) of three types of composite resin.

Materials and Methods: Three types of visible light-curing composite restorative material (Te-Econom, Tetric ceram and VOCO) were used in this study, The specimen disks of composites were prepared using Polyethylene mold $5 \mathrm{~mm}$ in diameter and $1 \mathrm{~mm}$ in height, The degree of conversion was measured for each group after storage for 7days in light-proof boxes containing storage media, The degree of conversion of the samples was measured by Fourier transform infrared spectroscopy (FTIR), One way analysis of variance and paired differences tests were used for statistical analysis. Results: The results revealed that there was a significant difference in the degree of conversion of the three types of composite resins when stored in all type of storage media as compared to dry samples(control group). Conclusions:The degree of conversion of the three types of composite resin was increased when stored in different storage media.

Key words: Storage Media, degree of Conversion, composite Resin.

الأهداف:الهدف من هذه الدراسة هو لتقييم تأثير البييسي, عصبر البرتقال والقهوة

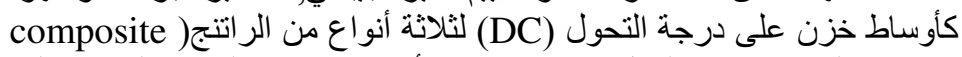

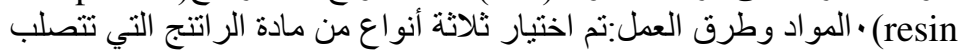

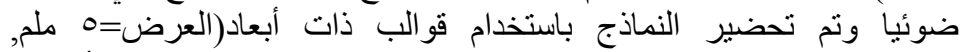

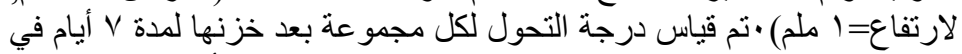

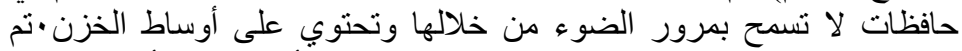

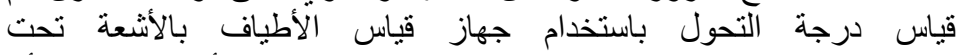

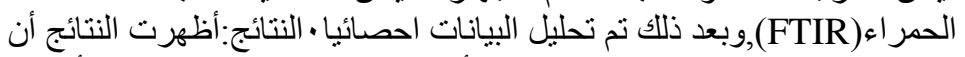

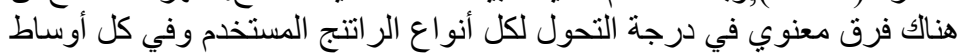

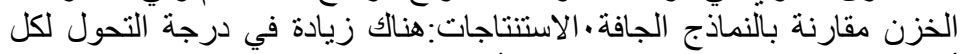
أنو اعز الر اتتج المستخدم عند خزنها في أوساط خزن مختلفة .
Assistant lect, Fanar T. H. AlJadwaa( $B D S, M S c)$ Assistant prof,

Moataz GH. S. Al-Shaekh $(B D S, M S c)$ Assistant prof, Amer A. Taqa $(B S c, M S c, p h D)^{*}$
College of Dentistry/university of Mosul/Department of Conservative Dentistry/Iraq

* College of Dentistry/university of Mosul/Department of Basic science /Iraq

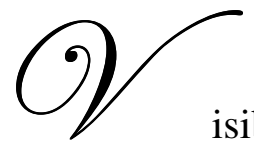

\section{INTRODUCTION}

isible light cured resin-based composites are the predominant restorative materials for both anterior and posterior restorations. In 2000, 94\% of U.S. dentists used visible-light curing units ${ }^{(1)}$. Light-cured composites allow the dentist to actively initiate the polymerization step being a significant advantage compared to auto cured composites ${ }^{(2,3)}$. 
The term composite material may be defined as a compound of two or more distinctly different materials with properties that are superior or intermediate to those of individual constituents ${ }^{(4)}$.

Modern composite materials consist of four major components: organic polymer matrix, inorganic filler particles, coupling agent, and the initiator-accelerator system ${ }^{(5)}$.

Ideally, dental restorative resin would have all of its monomer converted to polymer during polymerization. However, all dimethacrylate monomers exhibit considerable residual unsaturation in the final product ${ }^{(6)}$. Many studies examined the degree of conversion of resin by using the technique of fourier transform infrared spectroscopy (FTIR), ${ }^{(7,8-10)}$ since this technique can be done under room conditions and the sample preparation is simple without the problem of specimen thickness and nondestructive approach ${ }^{(11)}$.

The final DC of a resin depends on the chemical structure of the dimethacrylate monomer and the polymerization conditions, i.e. atmosphere, temperature, light intensity and photoinitiator concentration $^{(12)}$. The DC is one factor that affects clinical performance of resin composites ${ }^{(13)}$. It is important to evaluate the DC of polymeric adhesives, because with a low DC, a release of toxic substances is possible due to the development of a weak polymer network. This parameter is also considered a key factor in modulating the profile of the material, including a wide array of mechanical properties and potential biological adverse reactions ${ }^{(14)}$.

Fourier Transform Infrared Spectroscopy (FTIR) is an analytical technique used to characterize and identified the structural make-up of molecules. This technique measures the absorption of various infrared light wavelengths by the material of interest. These infrared absorption bands identify specific molecular components and structures. The majority of FTIRs operate in midinfrared radiation at region lies between $4000-400 \mathrm{~cm}-1$.

\section{MATERIALS AND METHOD}

The materials used in this study were three types of visible light-curing composite restorative material (Te-Econom, Tetric ceram and VOCO). Table (1)

Table 1. The material name, specification, composition and manufacturer

\begin{tabular}{|c|c|c|c|}
\hline $\begin{array}{c}\text { Material } \\
\text { brand name }\end{array}$ & Specification & Composition & Manufacturer \\
\hline Tetric ceram & $\begin{array}{l}\text { Hybrid resin- } \\
\text { composite }\end{array}$ & $\begin{array}{c}\text { The organic part: Bis-GMA, urethane } \\
\text { dimethacrylate and Schaan, } \\
\text { triethylene glycol ( } 20.2 \% \text { by weight). } \\
\text { Liechtenstien } 3 \text { The inorganic part: Barium } \\
\text { glass, yetterbium trifluoride Ba-Al- } \\
\text { fluorosilicate glass, highly dispersed } \\
\text { silicon dioxide and spheroide mixed } \\
\text { oxide (79\% by weight). } \\
\text { The Filler size is }(0.7 i ̀ m) .\end{array}$ & $\begin{array}{l}\text { Ivoclar } \\
\text { vivadent }\end{array}$ \\
\hline Te-econom & $\begin{array}{l}\text { Hybrid resin- } \\
\text { composite }\end{array}$ & $\begin{array}{l}\text { The organic part; Bis-GMA, urethane } \\
\text { dimethacrylate and triethylene glycol } \\
\text { dimethacrylate ( } 18.8 \% \text { by weight) and a } \\
\text { small amount of catalyst, stabilizers } \\
\text { and pigments }(0.21 \% \text { by weight }) \text {. } \\
\text { The inorganic filler ( } 81 \% \text { by weight. } \\
\text { The filler size is }(0.7 \mathrm{im}) \text {. }\end{array}$ & $\begin{array}{l}\text { Ivoclar } \\
\text { vivadent }\end{array}$ \\
\hline Arabesk & $\begin{array}{l}\text { Nano hybrid } \\
\text { composite }\end{array}$ & $\begin{array}{c}60 \% \text { by volum( } 76.5 \% \text { by weight }) \text { inorganic } \\
\text { fillers micro fillers } 0.05 \mu \mathrm{m} \text { small particle } \\
\text { fillers } 0.5-2 \mu \mathrm{m}\end{array}$ & $\begin{array}{l}\text { VOCO } \\
\text { Germeny }\end{array}$ \\
\hline
\end{tabular}

Journal of the $5^{\text {th }}$ Scientific Conference of Dentistry College, Apr. 2011 
For the determination of the degree of conversion; sixty samples were prepared and divided randomly into three groups $(\mathrm{n}=20)$ according to the type of composite resin used. Each group was subdivided into four subgroups $(\mathrm{n}=5)$ according to the storage media, the reminder subgroup was kept dry(control group).

The specimen disks of composites were prepared using Polyethylene mold $5 \mathrm{~mm}$ in diameter and $1 \mathrm{~mm}$ in height to determine DC. The composite resin material were directly applied into the mold over glass slab then covered by a celluloid strip and cured by conventional LED light curing unit according to the manufacturers' instructions. The light outputs of the curing units were measured before each testing procedure using radiometer directly to samples with exception of the thickness of the celluloid strip ${ }^{(15)}$.

The degree of conversion was measured in this study for each group after storage for 7 days in light-proof boxes containing storages media(Pepsi, coffee and orange juice) to avoid further exposure to light irradiation. Each specimen was individually pulverized into fine powder

with a mortar and pestle and 50 micrograms were mixed with $5 \mathrm{mg}$ of potassium bromide powder this mixture was poured into a metal mold

and compressed into a disc shape by Bruker press at a load of 10 tons and the samples become ready for measurement. While the uncured samples were prepared by placement on a special cell supplied by the manufacturers of Fourier transform infrared spectroscopy (FTIR), and becomes ready for measurement.

The degree of conversion of the samples were measured by Fourier transform infrared spectroscopy (FTIR). The degree of conversion on the tested samples was calculated according to the formula:

$$
\mathrm{DC}=((\mathrm{Ao}-\mathrm{At}) / \mathrm{Ao})^{*} 100
$$

Where A0 is peak area of the uncured composites $(1607 \mathrm{~cm}-1)$, At is the absorption of the peak immediately after polymerization $(1637 \mathrm{~cm}-1)$ and after 7 days storage period ${ }^{(15,16)}$.

\section{RESULTS}

In this study, one way analysis of variance at level $(\mathrm{p}<0.05)$ was performed. The degree of conversion values in $(\%)$ of storage samples were measured and compared with control group by Paired Differences test. (Table 2).

Table 2: Paired Differences Test for storage samples compared with control group(dry media).

\begin{tabular}{|c|c|c|c|c|c|c|c|}
\hline \multirow{2}{*}{ Storage Media } & \multicolumn{3}{|c|}{ Paired Differences } & \multirow{2}{*}{ df } & Sig. & \multirow{2}{*}{ State } \\
\cline { 2 - 8 } & Mean & Std. Deviation & Std. Error Mean & & & & \\
\hline COFFEE - DRY & 10.65333333 & 13.9811 & 3.6099 & 2.9511 & 14 & 0.01 & Sig \\
\hline ORANGE - DRY & 14.302 & 10.861 & 2.8043 & 5.1 & 14 & 0 & Sig \\
\hline PEPSI - DRY & 12.44133333 & 13.166 & 3.3994 & 3.6598 & 14 & 0 & Sig \\
\hline
\end{tabular}

The results revealed that all samples of the three types of composite resin stored in orange juice, Pepsi, and coffee have a significant difference $(\mathrm{p}<0.05)$ in the DC from dry samples (control group).

It was obvious from analysis there was no significant difference $(p>0.05)$ in the DC of composite resin between orange juice and Pepsi, and between coffee and Pepsi, but there was a significant difference between orange juice and coffee.( Table 3) 
Table 3: Paired Differences Test compared to samples stored in orange juice, Pepsi and coffee.

\begin{tabular}{|c|c|c|c|c|c|c|c|}
\hline \multirow{2}{*}{ Storage Media } & \multicolumn{3}{|c|}{ Paired Differences } & \multirow{2}{*}{$\mathrm{t}$} & \multirow{2}{*}{ Sig. } & \multirow{2}{*}{ state } \\
\cline { 2 - 5 } & Mean & Std. Deviation & Std. Error Mean & & & & \\
\hline ORANGE- COFFEE & 3.648666667 & 5.9818 & 1.5445 & 2.3624 & 14 & 0.03 & sig \\
\hline ORANGE - PEPSI & 1.860666667 & 3.97541 & 1.0264 & 1.8127 & 14 & 0.09 & not sig \\
\hline COFFEE - PEPSI & -1.788 & 3.95979 & 1.0224 & -1.7488 & 14 & 0.1 & not sig \\
\hline
\end{tabular}

Duncan's New Multiple Range Test showed the effect of storage media on three types of composite resin. It was obvious from this analysis that there was a non significant difference ( $>0.05)$ in DC of Tetric ceram and Voco composite resin stored in all storage media ,but they significantly differe $(\mathrm{p}<0.05)$ from Te-Econom composite resin samples.(Table 4)(Fig.1)

Table 4: Duncan's New Multiple Range Test showed the effect of storage media on three types of composite resin

\begin{tabular}{|l|l|l|l|l|}
\hline & Materials & Mean Square & F & Sig. \\
\hline \multirow{2}{*}{ Between Groups } & \multirow{2}{*}{ TE-ECONOM } & 81.33760667 & 1.33000479 & 0.299 \\
\cline { 3 - 5 } Between Groups & \multirow{2}{*}{ VOCO } & & & \\
\hline \multirow{2}{*}{ Between Groups } & \multirow{2}{*}{ TETRIC- CERAM } & 327.3153333 & 12.03520061 & 0.000 \\
\cline { 3 - 5 } & & & & 0.000 \\
\hline
\end{tabular}

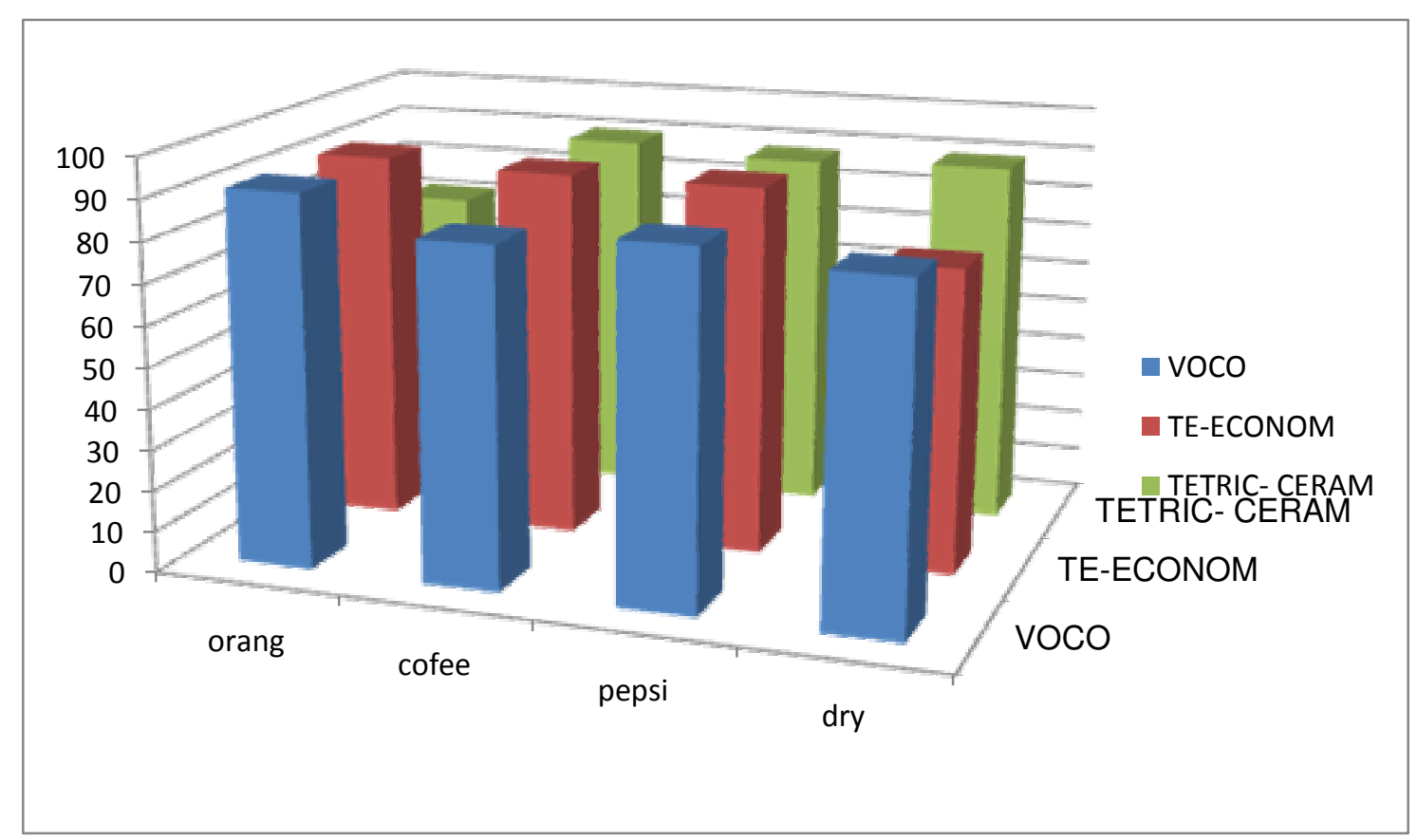

Figure 1. The effect of storage media on the degree of conversion of three types of composite resin 


\section{DISCUSSION}

The physical, mechanical and biological properties of composite resin are strongly influenced by the DC achieved by organic matrix ${ }^{(15)}$. Ideally, a resin material would have all of its monomer converter to polymer during polymerization ${ }^{(15)}$.

Fourier transformation infrared spectroscopy (FTIR) has been proven to be a powerful technique for measuring the DC and has been widely used as available method ${ }^{(17)}$.

The DC is one factor that affects clinical performance of resin composites ${ }^{(13) .}$ This parameter is also considered a key factor in modulating the profile of the material, including a wide array of mechanical properties and potential biological adverse reactions ${ }^{(14)}$.

The DC of three types of composite resin (Te-Econom, Tetric ceram and VOCO) was significantly increased when the samples stored in orange juice, Pepsi and coffee as compared to dry samples(Table 2). This result may be attributed to lower $\mathrm{pH}$ value of the storage media than neutral, this result agree with Tosun et $\mathrm{al}^{(15)}$ who found that the DC of resin material was increased when stored in different $\mathrm{pH}$.

The result also revealed that the three types of composite resin samples stored in orange juice showed a significant difference $(\mathrm{p}<0.05)$ in the DC when compared to samples stored in coffee (Table 3) this is because the lower $\mathrm{pH}$ value of orange juice than coffee, where as samples stored in Pepsi showed a non significant difference $(\mathrm{p}>0.05)$ in the DC as compared to samples stored in orange juice and coffee (Table 3). This is due to the $\mathrm{pH}$ value of Pepsi lies between that of orange juice and coffee ${ }^{(18,19)}$. This finding agree with Chadwick et,al ${ }^{(20)}$ who found that there was a non significant difference between composite resin samples stored in Pepsi and coffee.

Finally, the result found that there was a non significant difference in DC of Tetric ceram and VOCO composite resin samples stored in all storage media, but they significantly different from Te-Econom composite resin samples (Table 4). This is due to the difference of organic matrix of Te-Econom from Tetric ceram and VOCO composite resin (Table 1).This result agree with the findings of Filho et $\mathrm{al}^{(22)}$ who found that differences in the viscosity of organic matrix have an influence in the DC of composite resin material.

\section{CONCLUSIONS}

Within the limitations of this in vitro study the following conclusions were drawn:

There was a significant difference in the DC of the three types of composite resin when stored in different media as compared with dry samples.

The three types of composite resin that stored in Pepsi showed a non significant different in the DC when compared to that stored in orang juice and coffee.

Samples stored in orange juice showed a significant difference in the DC when compared to that stored in coffee.

The DC of Tetric ceram and VOCO composite resin samples significantly differ from TeEconom composite samples when stored in different $\mathrm{pH}$.

\section{REFERENCE}

1. Aravamudhan K, Floyd CJ, Rakowski D, Flaim G, Dickens SH, Eichmiller FC.Fan PL. Light-emitting diode curing light irradiance and polymerization of resin-based composite. Am J Dent Assoc (1999);137:213-223.

2. Solomon CS, Osman YI. Evaluating the efficacy of curing lights. SADJ(2006);54:357-362.

3.Norbert Kramer, Ulrich Lohbauer, Franklin Garcia-Godoy, \& Roland Frankenberger. Light curing of resin-based composites in the LED era. Am J Dent (2008);21:135-142.

4.Soderholm KJ.Philips scince of Dental Material, 10th ed., Philadelphia, W.B Saunders Co. ( 1996), U.S.A, ch 12.

5. Amer AS. Degree of conversion and Curing Depth of Composite Resin. M.Sc thesis(2005); collage of Dentistry, University of Mosul.

6. Ruyter I E, Oysaed H. Analysis and characterization of dental polymers. Critical Reviews in Biocompatibility (1988);4: 247-279.

Journal of the $5^{\text {th }}$ Scientific Conference of Dentistry College, Apr. 2011 
7.Ferracane JL, Greener EH. Fourier transform infrared analysis of degree of polyme ization in unfilled resinsmethods comparison. J Dent Res ( 1984);63: 1093-5.

8.Sideridou I, Tserki V, Papanastasiou G. Effect of chemical structure on degree of conversion in light-cured dimethacrylate-based dental resins. Biomaterials (2002);23:1819-29.

9.Moin Jan C, Nomura Y, Urabe H, Okazaki M. Shintani H. The Relationship between leachability of polymerization initiator and degree of conversion of visible light-cured resin. J Biomed Mater Res (Appl Biomater) ( 2001);58:42-6.

10.Bouschlicher MR, Rueggeberg FA, Wilson BM. Correlation of bottom-to-top surface microhardness and conversion ratios for a variety of resin composite compositions. Oper Dent( 2004);29:698-704.

11.Brian CS. Fundamentals of Fourier transform infrared spectroscopy. CRC Press Inc.( 1996);.p15-53,87-125.

12. Serdar Üs^ümez, Tamer Büyüky1lmaz, Ali I.hya Karaman and Beniz Gündüz Degree of conversion of two lingual retainer adhesives cured with different light sources. European Journal of Orthodontics (2005); 27 :173179 .

13. Miyazaki M, Onose H, Iida N, Kazama H. Determination of residual double bonds in resin-dentin interface. Dental Materials Journal(2003); 19: 245-251.

14. Ferracane J L, Greener E H. The effect of resin formulation on the degree of conversion and mechanical properties of dental restorative resins. Biomaterials (1986);20: 121-131

15. Gul Tosun, Nilgun Ozturk, Yagmur Sener, Beniz Gunduz. Effect Of Light Curing Units And Storage Time on The Degree Of Conversion Of Fissure Sealants. Rev. Clin. Pesq. Odontol. (2009); Curitiba, v.5, n.2, 111-119.

16.Sideridou I, Tserki V, Papanastasiou G. Effect of Chemical Structure on Degree of Conversion in Light-Cured Dimethacrylate-base Dental Resin. Biomaterials (2002);23(8),1819-29.

17.Imazato S, Tarumi H, Kobayashi K, Hiraguri H, Oda K, Tsuchitani Y. Relationship between the degree of conversion and internal S. Dental Materials Journal (2001); 17 :182 178-183.

18. Wongkhantee S., Patanapiradej V., Maneenut C., Tantbirojn D. Effect of acidic food and drinks on surface hardness of enamel, dentine, and tooth-coloured filling materials. Journal of Dentistry(2005); 1-7

19. Grobler SR, Senakal PJ, Laubscher JA. In vitro demineralization of enamel by orange juice, Pepsi Cola and Diet Pepsi cola. Clinical Preventive Dentistry(1990);12:5-9.

20. Chadwick RG, McCabe JF, Walls AW, Storer R. The effect of

storage media upon the surface microhardness and abrasion resistance of three composites. Dental Materials Journal ( 1990);6: 123-8.

21. Nuran Yanikoğlu, Zeynep Yeşil Duymuş and Baykal Yilmaz Effects of different solutions on the surface hardness of composite resin Materials. Dental Materials Journal (2009); 28(3): 344-35.

22.Jaime DN Filho, Laiza T Poskus,Jose Guilherme A Guimaraes.Degree of conversion and plasticization of dimethacrylate based polymeric matrices:influence of light curing mode. J of Oral Scinence(2008),Vol.50,No.3,315321. 